\title{
REPRODUCTIVE DISTURBANCE CAUSED BY AN S-TRIAZINE HERBICIDE IN PIGS
}

\author{
Tihomira GOJMERAC $^{1 *}$, Marija UREMOVIĆ ${ }^{2}$, Z. UREMOVIĆ ${ }^{2}$, S. ĆURIĆ ${ }^{3}$ and \\ Nina BILANDŽIĆ ${ }^{1}$ \\ ${ }^{1}$ Croatian Veterinary Institute, Zagreb, Savska 143, Croatia; ${ }^{2}$ Faculty of Agriculture, \\ University of Zagreb, Croatia; ${ }^{3}$ Veterinary Faculty, University of Zagreb, Croatia
}

(Received March 20, 1998; accepted June 15, 1998)

\begin{abstract}
The aim of the study was to assess the effect of subacute treatment with a low dose of atrazine (1,3,5-triazine-2,4-diamine, 6-chloro-N-ethyl-N'-(1-methylethyl), an s-triazine herbicide, on endocrine oestrus regulation in gilts. A group of nine gilts $\left(F_{1}\right.$ generation of Swedish Landrace $\times$ Large Yorkshire $)$ were treated with $1 \mathrm{mg}$ atrazine/ $\mathrm{kg}$ body mass daily, mixed to the feed for 19 days before the onset of expected oestrus. Blood samples were obtained by cranial vena cava puncture three times daily at 3-h intervals on five post-treatment days, i.e. before and during oestrus. The serum concentration of oestradiol-17 $\beta\left(E_{2}\right)$ was determined by the fluoroimmunochemical method. On Day -2 before the onset of expected oestrus, a significantly lower $(\mathrm{P}<0.001) \mathrm{E}_{2}$ concentration was measured in the serum of treated gilts $(31.25 \pm 1.95$ and $39.32 \pm 1.38 \mathrm{pg} / \mathrm{mL})$ than in the control pigs $(51.43 \pm 1.29$ and $68.59 \pm 2.99 \mathrm{pg} / \mathrm{mL})$. In contrast, the $\mathrm{E}_{2}$ concentration measured in the serum of treated animals was significantly higher $(\mathrm{P}<0.001)$ on the day of the expected onset of oestrus and on the subsequent two days (35.43 \pm $1.85,53.92 \pm 1.98$ and $60.32 \pm 2.35 \mathrm{pg} / \mathrm{mL}$, respectively) than in the control animals $(13.52 \pm 1.79,21.53 \pm 1.35$ and $20.05 \pm 1.46 \mathrm{pg} / \mathrm{mL}$, respectively). Insufficient serum $\mathrm{E}_{2}$ concentration of the treated gilts resulted in a failure of expected oestrus, as indicated also by the state of dioestrus demonstrated by histopathological examination of the uterus.
\end{abstract}

Key words: s-triazine herbicide, atrazine, reproduction, gilts, oestrus, oestradiol-17 $\beta\left(\mathrm{E}_{2}\right)$

Disturbances in the reproductive cycle of gilts and sows may entail considerable economic losses in pig production. Such disturbances may be caused by various organochemical environmental contaminants that may enter the animal's organism either directly or indirectly via feed and water. Pesticides are regarded as common environmental contaminants which form an integral part of the biosphere due to their continuous use and stability. Although the environ-

\footnotetext{
*Corresponding author: Tel.: 38516190 838; Fax: 38516190 841;
}

E-mail: Tihomira.Gojmerac@mavi.veinst.hr 
mental concentrations of pesticide residues have recently been considerably reduced by strict control and restrictive measures, the impact of past contamination upon the human and animal body is being further deteriorated by daily contact with pesticides. Of the pesticides, herbicides (especially s-triazine herbicides, e.g. atrazine, prometryne, ametryne, atratone, simazine, etc.) are used the most commonly. Following long-term use of atrazine as a plant-protecting substance, residues of this contaminant have been detected in the samples of underground and surface waters (Vidaček et al., 1994) as well as of pig watering systems (Gojmerac et al., 1996a). During the spring, the concentration of atrazine measured in pig drinking water samples was found to considerably exceed the maximal allowed concentration $(0.1 \mu \mathrm{g} / \mathrm{l})$ specified by the Act on Drinking Water Safety (Official Gazette of the Republic of Croatia, No. 46/1994).

This finding and results of previous studies indicate that low doses of atrazine inhibit biochemical reactions responsible for normal reproductive function in mammals (Šimić et al., 1994; Gojmerac et al., 1996b). This prompted us to study the effect of a low atrazine dose on the onset of the subsequent expected oestrus in gilts. With this in mind, we determined the concentration of oestradiol-17 $\beta\left(\mathrm{E}_{2}\right)$ in gilt serum after subacute treatment, to assess the endocrine activity of the ovary immediately before the onset of, and during, the expected oestrus.

\section{Materials and methods}

\section{Treatment and blood sampling}

Female pigs (gilts, $n=9$ ), cross-bred between Swedish Landrace and Large Yorkshire, body mass 90-100 kg, aged 6-7 months, were administered $1 \mathrm{mg}$ atrazine [1,3,5-triazine-2,4-diamine, 6-chloro-N-ethyl-N'-(1-methylethyl)]/kg body mass in the feed daily for 19 days of the oestrous cycle, starting from the onset of oestrus (Day 0). A control group consisted of 9 gilts. During the experiment, the animals were kept under the same conditions and given the same feed mix. The concentration of the required nutrients in complete feed was determined according to recommendations of the National Research Council (NRC, 1988). Thus, $1 \mathrm{~kg}$ feed mix fed to gilts weighing $\leq 50$ and $60-100 \mathrm{~kg}$ contained 13.43\% MJ - ME and 16.30\% CP, and 13.67\% MJ - ME and 15.03\% $\mathrm{CP}$, respectively. Blood samples were obtained by cranial vena cava puncture three times daily at 3-h intervals on five post-treatment days, immediately before the onset of, and during, the subsequent expected oestrus. Blood samples were kept at room temperature for $2 \mathrm{~h}$, and then centrifuged at $2500 \mathrm{rpm}$ for $15 \mathrm{~min}$, when the serum was separated and stored at $-15^{\circ} \mathrm{C}$ until analysis. 


\section{Determination of oestradiol-17 $\beta$}

The concentration of $E_{2}[1,3,5$ (10)-estratriene-3,17 $\beta$-diol $]$ in the serum of experimental animals was determined by the fluoroimmunochemical method described by Lövgren et al. (1984). The $\mathrm{E}_{2}$ assay kit was obtained from Wallac Oy, Turku, Finland. Atrazine for analytical use (p.a.) was obtained from Ciba-Geigy, Basle, Switzerland.

\section{Statistical analysis}

The data obtained by steroid hormone determination were processed using the STATGRAPHICS Version 4 statistical program. The results are expressed as means of three measurements and standard errors. Student's $t$-test was employed to determine the levels of significance $(\mathrm{P})$ of the difference in the mean serum $17 \beta-E$ concentration between the treated and control animals.

\section{Results}

The serum $\mathrm{E}_{2}$ concentrations of experimental gilts during the oestrous cycle are shown in Fig. 1. The measurement preceded the experiment in which the gilts were treated with the s-triazine herbicide, in order to predict the day of oestrus onset.

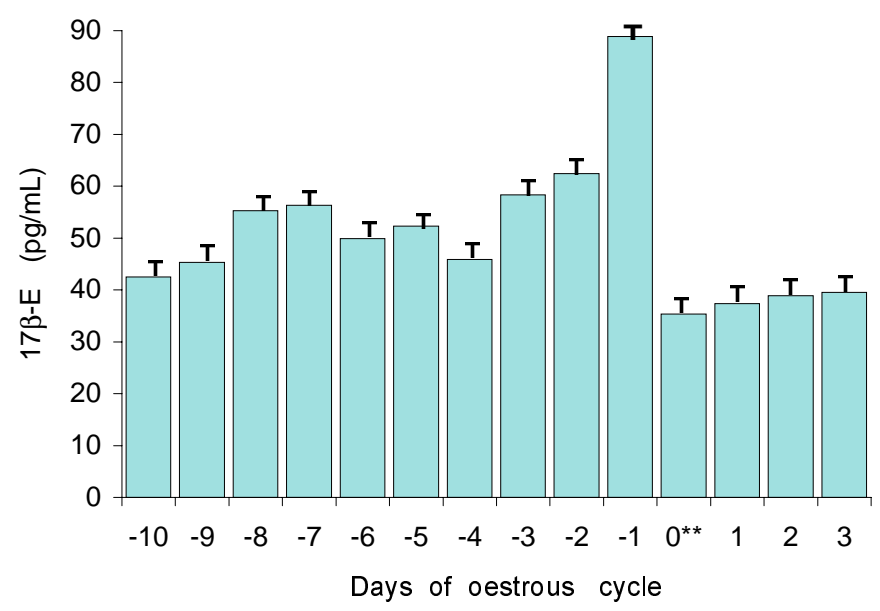

Fig. 1. Mean $( \pm \mathrm{SE})$ serum concentration of oestradiol-17 $\beta(17 \beta-\mathrm{E})$ in gilts* during several days of the oestrous cycle; *cross-bred between Swedish Landrace and Large Yorkshire $(n=9)$, weighing $80-100 \mathrm{~kg}$ and aged 6-7 months; ${ }^{* *}$ onset of oestrus 
Figure 2 presents results of the measurement of $\mathrm{E}_{2}$ concentration in the serum of control and experimental gilts during the five post-treatment days, i.e. immediately before and during the onset of the subsequent expected oestrus. In the control group, a significantly higher $(P<0.001)$ serum concentration of $E_{2}$ of $68.59 \pm 3.67 \mathrm{pg} / \mathrm{mL}$ was measured on the day preceding the onset of expected oestrus (Day -1), whereas the lowest hormone concentration of $13.52 \pm$ $1.79 \mathrm{pg} / \mathrm{mL}$ was measured on the day of the onset of oestrus (Day 0 ). In the experimental group, a gradual increase in serum $\mathrm{E}_{2}$ concentration was observed. Thus, the concentration of $\mathrm{E}_{2}$ was $31.25 \pm 1.95 \mathrm{pg} / \mathrm{mL}$ on the first day of measurement (Day -2) and increased to $59.12 \pm 2.10 \mathrm{pg} / \mathrm{mL}$ by the last day of measurement (Day 2). Unlike the control animals, the treated gilts failed to exhibit overt signs of the onset of subsequent expected oestrus (an active or passive oestrous reflex). Uterine histopathology in the treated animals indicated a state of uterine rest (dioestrus) (Fig. 3).

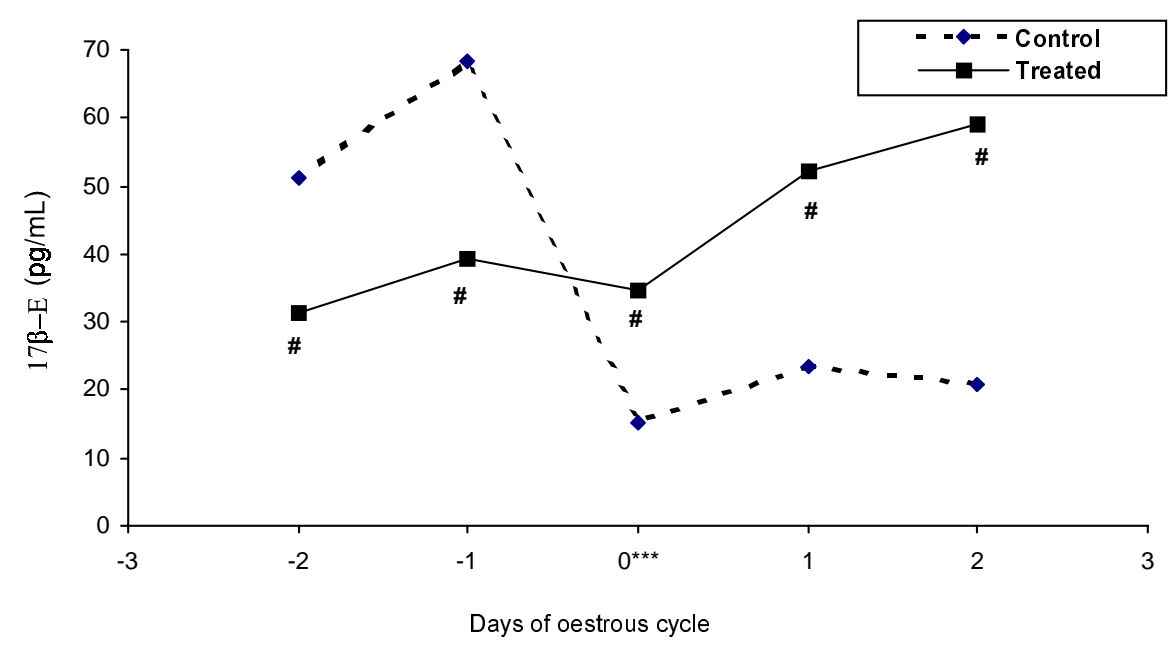

Fig. 2. Mean $( \pm \mathrm{SE})$ serum concentration of oestradiol-17 $\beta\left(\mathrm{E}_{2}\right)$ in gilts* after atrazine treatment** [*cross-bred between Swedish Landrace and Large Yorkshire $(\mathrm{n}=9)$, weighing $80-100 \mathrm{~kg}$, aged 6-7 months; **treatment with $1 \mathrm{mg}$ atrazine/kg body mass daily for 19 days of oestrous cycle; *** onset of oestrus; \# P $<0.001$ vs. control; statistical evaluation by Student's $t$-test]

\section{Discussion}

An increase in the serum concentration of $E_{2}$ to the maximal value is a precondition for the hypophyseal secretion of luteinizing hormone (LH) and for the onset of oestrus followed by ovulation in female pigs (Brown-Grant, 1997). The presented serum $\mathrm{E}_{2}$ concentrations determined during the oestrous cycle in 
gilts (Fig. 1) corresponded to the basic physiologic pattern mentioned above, manifesting in an abrupt increase in serum $\mathrm{E}_{2}$ concentration immediately before the onset of oestrus. The results obtained were consistent with those published elsewhere (Guthrie et al., 1972; Van de Wiel et al., 1981). Upon atrazine treatment, the gilts failed to show the signs of the expected onset of oestrus, while the histopathological findings resembled the phase of uterine rest (dioestrus) (Fig. 3).The failure of oestrus significantly $(\mathrm{P}<0.001)$ correlated with the decreased serum concentration of $\mathrm{E}_{2}(39.43 \pm 2.01 \mathrm{pg} / \mathrm{mL})$ as compared to the physiological, i.e. control, values of the hormone $(68.59 \pm 3.67 \mathrm{pg} / \mathrm{mL})$ immediately before the onset of the expected oestrus (Day -1) (Fig. 2).

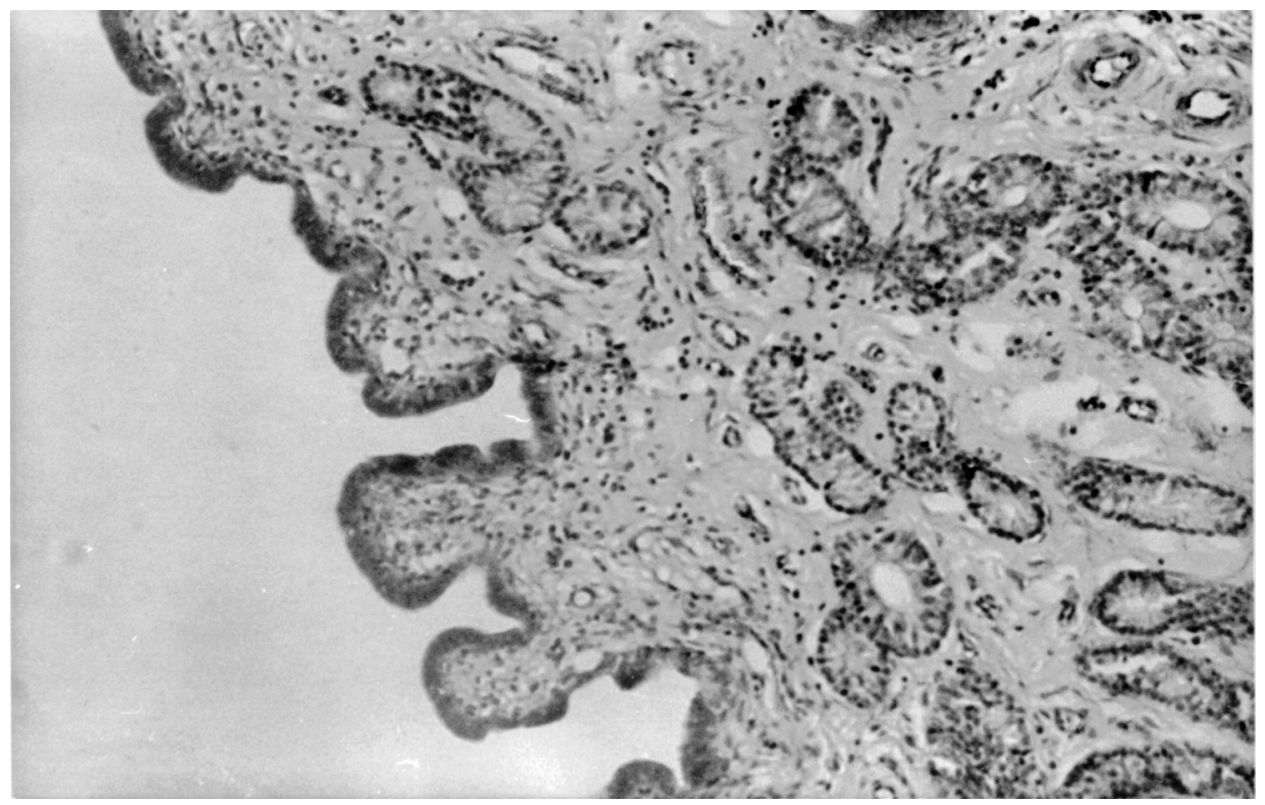

Fig. 3. Papillary endings of the endometrium in gilts after atrazine treatment $(1 \mathrm{mg} / \mathrm{kg}$ body mass daily for 19 days). Haematoxylin and eosin (HE) staining, magnification $\times 200$

Although $24 \mathrm{~h}$ before the expected oestrus the serum concentration of $\mathrm{E}_{2}$ was significantly lower in the treated gilts than in the control animals, the values of $\mathrm{E}_{2}$ showed a slight but steady increase, so that a hormone level of $59.12 \pm$ $2.11 \mathrm{pg} / \mathrm{mL}$ was measured on day 24 of the oestrous cycle (Day 2). This increase in serum $E_{2}$ concentration in the treated gilts suggested that the balance was being gradually restored at the hypophysis-ovary level via a feedback mechanism, resulting in an abundant adenohypophyseal release of LH. This hypothesis ap- 
pears to be supported by the observed occurrence of delayed oestrus (an active or passive oestrous reflex) in the treated gilts after Day 26 of the oestrous cycle.

The results show that the dose of atrazine used in the experiment $(1 \mathrm{mg} / \mathrm{kg}$ body mass in the feed daily for 19 days of the oestrous cycle) influenced the endocrine activity of the ovary, manifesting itself as a short-term delay in the onset of the subsequent oestrus.

The dose of atrazine used in the study is not expected to accumulate in the animal body via feeding and watering, provided that the agricultural use of the herbicide is controlled. However, undegraded atrazine residues remain in the soil for quite a long time due to the poor chemical reactivity of atrazine (Capriel et al., 1985), and from the soil they can reach waters and watering systems. Atrazine was also detected in maize (Norris and Fong, 1983), one of the constituents of the gilts' feed mix. As atrazine is a fat-soluble substance, it may accumulate in the fatty tissue of gilts and especially of sows.

Accordingly, the ever increasing environmental presence of atrazine makes it more likely that the compound has a toxicological impact on reproduction in female pigs. New data obtained in ecology-oriented studies on the possible reproductive disturbances caused by atrazine in pigs may prove useful in the control of reproductive and other biochemical processes affecting the success of pig breeding and production.

\section{Acknowledgements}

This study was supported by Project No. 3-03-355 of the Ministry of Science and Technology of the Republic of Croatia.

\section{References}

Act on Drinking Water Safety (1994): Official Gazette of the Republic of Croatia No. 46, June 13, 1994, pp. 1569-1574.

Brown-Grant, K. (1997): Physiological aspects of the steroid hormone-gonadotropin interrelationship. In: Reproductive Physiology II, Vol. 13, University Park Press, Baltimore, pp. 57-83.

Capriel, P., Haisch, A. and Khan, S. U. (1985): Distribution and nature of bound (nonextractable) residues of atrazine in mineral soil nine years after the herbicide application. J. Agr. Food Chem. 33, 567-569.

Gojmerac, T., Kartal, B., Bilandžić, N., Roić, B. and Rajković-Janje, R. (1996a): Seasonal atrazine contamination of drinking water in pig-breeding farm surrounding in agricultural and industrial areas of Croatia. Bull. Environ. Contam. Toxicol. 56, 225-230.

Gojmerac, T., Kartal, B., Ćurić, S., Žurić, M., Kušević, S. and Cvetnić, Ž. (1996b): Serum biochemical changes associated with cystic ovarian degeneration in pigs after atrazine treatment. Toxicology Letters 85, 9-15.

Guthrie, H. D., Henricks, D. M. and Handlin, D. L. (1972): Plasma estrogen, progesterone and luteinizing hormone prior to estrus and during pregnancy in pigs. Endocrinology 91, 675-679. 
Lövgren, T., Hemmilä, I., Pettersson, K., Eskola, J. V. and Bertoft, E. (1984): Determination of hormones by time-resolved fluoro-immunoassay. Talanta, pp. 909-916.

National Research Council (1988): Nutrient requirements of swine. Washington, D. C.

Norris, R. F. and Fong, J. L. (1983): Localization of atrazine in corn (Zea mays), oat (Avena sativa) and kidney beans (Phaseolus vulgaris) leaf cells. Weed Sci. 31, 664-771.

Šimić, B., Kniewald, J. and Kniewald, Z. (1994): Effects of atrazine on reproductive performance in the rat. J. Appl. Toxicol. 14, 401-404.

Van de Wiel, D. F. M., Erkens, J., Koops, W., Vos., E. and Van Landeghem, A. A. J. (1981): Periestrous and midluteal time courses of circulating LH, FSH, prolactin, estradiol-17 $\beta$ and progesterone in the domestic pig. Biol. Reprod. 24, 223-233.

Vidaček, Ž., Drevenkar, V., Husnjak, S., Sraka, M. and Karavidović, P. (1994): Nitrates, pesticides and heavy metals in soil and drained areas, and in water of the Karašica and Vučica rivers basin. Proceedings of the Scientific Meeting: Agriculture and Water Management. Bizovačke Toplice, Croatia, July 1994, pp. 211-222. 